\title{
A correlation analysis of english learning strategies and english reading competencies of Aatthayomsueksa 1 students under Nakhon Ratchasima Provincial Administration organization in Thailand
}

\author{
Un análisis de correlación de las estrategias de aprendizaje del inglés y las competencias de \\ lectura en inglés de los estudiantes de Aatthayomsueksa 1 bajo la organización de la \\ Administración Provincial de Nakhon Ratchasima en Tailandia
}

SIRIPITAKCHAI, Suwannee ${ }^{1}$
TIYAWONGSUWAN, Siripan

\begin{abstract}
English reading competencies and English learning strategies are fundamental both in studying academic subjects and in the field of technology. If both of them are necessities, they should be related and developed to improve our students' learning. It was found that students' mean score was low in an English reading competencies test; however, students' scores were average in English learning strategies. Canonical variable analysis indicated that affective, compensatory and metacognitive strategies were efficiently related to literal comprehension. Moreover, memory strategies were efficiently related to critical comprehension.

Key words: english learning strategies, english reading competencies, correlation analysis, canonical analysis.

Resumen

Las competencias lectoras en inglés y las estrategias de aprendizaje del inglés son fundamentales tanto en el estudio de materias académicas como en el campo de la tecnología. Si ambas son necesarias, deben relacionarse y desarrollarse para mejorar el aprendizaje de los estudiantes. Se encontró que la puntuación media de los estudiantes fue baja en una prueba de competencia lectora en inglés; sin embargo, los puntajes fueron promedio en estrategias de aprendizaje de inglés. El análisis de variables canónicas indicó que las estrategias afectivas, compensatorias y metacognitivas se relacionaron eficientemente con la comprensión literal. Además, las estrategias de memoria se relacionaron eficazmente con la comprensión crítica.

Palabras clave: estrategias de aprendizaje del inglés, competencias lectoras en inglés, análisis de correlación, análisis canónico.
\end{abstract}

\footnotetext{
1 Student in Education Master Degree, Faculty of Education Research and Evaluation, Nakhon Ratchasima Rajabhat University, Nakhon Ratchasima Province, Thailand. E-mail: suwannee.pcp@gmail.com

${ }^{2}$ Adviser in Education Master Degree, Faculty of Education Research and Evaluation, Nakhon Ratchasima Rajabhat University, Nakhon Ratchasima Province, 30000, Thailand. E-mail: siripantiya@gmail.com
} 


\section{Introduction}

Reading is an essential skill in the information technology era. There are a variety of texts used to convey the writer's ideas. Some are beneficial, yet on the other hand, some are fake. Thus, text concepts and communication are explored and understood through reading competencies (Wiriyachitra, et al, 2012). Thai students should continually and effectively practice their reading competencies, particularly, in English. It is a foreign language in Thailand. They might not be familiar with it; however, it is important in their studies.

Due to the importance of reading competencies in English, they should be reviewed. English reading competencies are used in a process of text interpretation or text understanding of words or symbols that the writers use to convey their concepts, emotions or impressions to the readers. These competencies were examined and grouped into 3 types: literal, interpretative, and critical competencies (Bowornwattanaset, 2015).

Literal competencies are reading competencies about recognizing the meaning of words and the main idea in the text, indicating the text details, pronoun substitution, sequencing the events, and defining the character of people in the text. Furthermore, following the instructions and exposition can be clarified (Bowornwattanaset, 2015).

Interpretative competencies are reading competencies about concluding, inferring and expressing the text opinion. Moreover, forecasting a continued event, explaining the relationship between the reason and the effect, identifying the main idea that may not be seen in the text, and showing the mind mapping of the text should be considered. Writing the conclusion and ascribing the character or personality should be considered as well (Bowornwattanaset, 2015).

Critical competencies are reading competencies about integrating the reader's emotion and experience to the text, mentioning writing objectives, analyzing events between opinion and fact, and identifying valuable or useless text. Additionally, reflecting writer's emotion or feeling, specifying the meaning of the writer's idea, and connecting the text's events are also considered (Bowornwattanaset, 2015).

The criteria mentioned above were examined in an English reading competency test to check student's level as a pre-test. The data could be used and considered as fundamental information not only to improve teachers' methodologies and instructions, but also to upgrade students' English reading competencies (fig. 1).

Figure 1

Concept framework of the Correlation Analysis of English Learning Strategies and English Reading Competencies

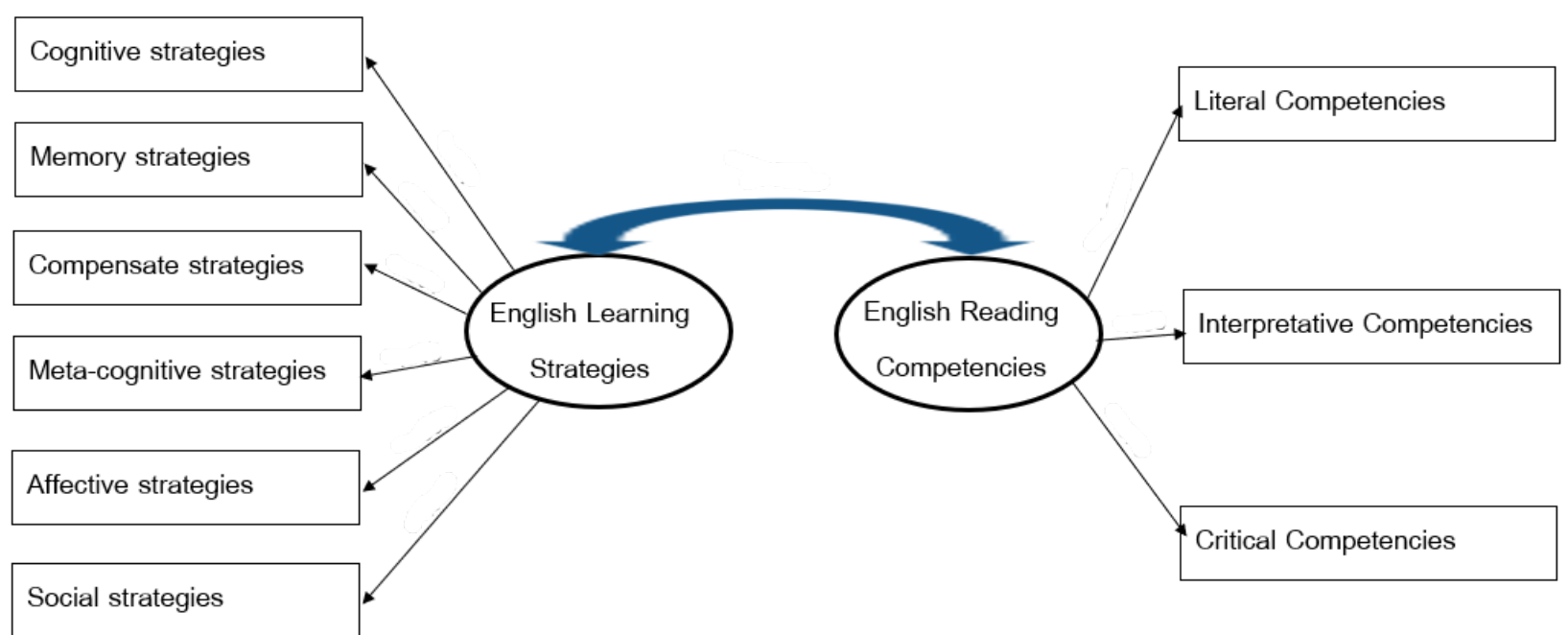


In addition, students have their own learning styles and strategies. English learning strategies are the means of student effort to make their English subject not only easier to understand and remember, but also, more enjoyable and applicable (Oxford, 1990; 2003). Likewise, Schumaker and Deshler (2006) defined a learning strategy as "an individual's approach to a task. It includes how a person thinks and acts when planning, executing, and evaluating performance on a task and its outcomes". People also apply a variety of strategies to help them organize and memorize information. Therefore, English teachers should teach students how to learn English, rather than only teaching them specific curriculum content or specific skills. Students can use their learning strategies in their education throughout their lives (Oxford et al, 2014).

Oxford (1990; 2003) classified English learning strategies into 2 main subcategories: direct strategies and indirect strategies. Direct strategies occurred autonomously within the students themselves. Meanwhile, indirect strategies arose through social learning and practice.

Direct strategies consist of cognitive strategies, memory strategies, and compensatory strategies (Oxford, 1990; 2003). Cognitive strategies are learning strategies used in receiving information, then using analytic and discretionary thinking to connect, group, translate and summarize the main ideas. Memory strategies are the means of learning strategies in gaining, remembering and recognizing to integrate their own knowledge with new information. Compensatory strategies are learning strategies learners use to interpret the context around themselves.

Indirect strategies consist of meta-cognitive strategies, affective strategies, and social strategies (Oxford, 1990; 2003). Meta-cognitive strategies are the process of learning and checking their own knowledge, opinion, and understanding in order to define learning objectives, learning plans, and learning abilities. Affective strategies are defined as learning techniques used to create their own emotion and confidence so that they could continue their efforts towards achieving their own goals. Social strategies are the procedures of learning by asking for help from other people such as friends, teachers, parents, etc., including participating in activities.

There are many research findings representing the relationship between English learning strategies and English competencies. However, they were explored in fragmented variables. In real life, students use all English learning strategies in their education. Is it the overall relationship between English learning strategies and English competencies.?

To answer this question, the research objectives was to explore whether there is a correlation between English learning strategies and English reading competencies in Thai students.

\section{Methodology}

\subsection{Research sampling}

This is a quantitative research. There are 57 secondary schools under Nakhon Ratchasima Provincial Administration Organization. There were 23,388 students in 2020. They were administrated by local organization. The schools were grouped into 7 groups (ONESQA, 2017, p. 3) as shown in table 1. 
Table 1

Numbers of students in secondary schools under Nakhon

Ratchasima Provincial Administration Organization in 2020

\begin{tabular}{ccccc} 
Size of schools & $\begin{array}{c}\text { Numbers of } \\
\text { schools }\end{array}$ & Numbers of all students & Numbers of class & $\begin{array}{c}\text { Numbers of } \\
\text { Matthayomsueksa 1 } \\
\text { students }\end{array}$ \\
\hline 1 & 0 & 0 & 0 & 0 \\
\hline 2 & 11 & 1,774 & 13 & 315 \\
\hline 3 & 15 & 3,864 & 39 & 695 \\
\hline 4 & 16 & 6,135 & 29 & 1,132 \\
\hline 5 & 9 & 5,312 & 61 & 959 \\
\hline 6 & 6 & 11,303 & 0 & 2,240 \\
\hline 7 & 0 & 0 & 170 & 0 \\
\hline Total & 57 & 23,388 & 5,303 \\
\hline
\end{tabular}

Two-Stage random sampling method was used. Simple random sampling method was used in the first stage. There are eleven schools according to this ratio (2: 3: 3: 2: 1). Cluster random sampling method was used in the second stage: one school one class. There were 11 classrooms with 314 students in Matthayomsueksa 1. Matthayomsueksa 1 students were chosen because they were the first level of secondary school in order to know their background and well-prepare in English teaching.

\subsection{Collecting data instrument}

There were 2 experiments; Behavior questionnaire on English learning strategies and English reading competencies test. They were examined by the advisor and academic experts in English, Psychology and educational evaluation.

1. There were 91 items in behavior questionnaire on English learning strategies. They were measured on a five point rating scale; always, very often, sometimes, rarely and never. Sixty items were selected and well examine with questionnaire discrimination and questionnaire reliability (.9787).

2. The English reading competency test consisted of 50 items about literal, interpretative, and critical comprehension. They were multiple choice. Thirty items were selected and well examined with the index of item objective congruence $(.60-1.00)$, test difficulty $(.23-.49)$, test discrimination $(.25-.46)$ and test reliability (.8436).

\subsection{Data analysis}

Means, standard deviation, Pearson correlation analysis and canonical analysis were used to analyze the data in order to explore whether there is a correlation between English learning strategies and English reading competencies in Thai students.

Canonical analysis was considered and explored. It is a statistical instrument used to identify and measure the associations among two sets of variables. It is appropriate in the same situations where multiple regression would be, but there are multiple intercorrelated outcome variables. The advantages of canonical correlation analysis are that its estimates of canonical direction matrices are asymptotically efficient, its test statistics for determining the number of canonical covariates always has a chi-squared distribution asymptotically, and it is straight forward to construct tests for variable selection (Lee and Yoo, 2014). The fundamental asymptotic limits of canonical correlation analysis: 1) all variables and their linear combinations have a normal distribution; 2) N is assumed to be much larger than the number of observable variables $(p) ; 3)$ the relationships between variables in each group 
and between groups must be linear; 4) variance of each variable in a group or between groups must be a constant at all levels. 5) A correlation matrix must not have an ill-conditioning matrix. (Meejang, 2001; Lee and Yoo, 2014).

\section{Results and discussion}

The results of the correlation analysis of English learning strategies and English reading competencies of Matthayomsueksa 1 students under Nakhon Ratchasima Provincial Administration Organization in Thailand were as follows:

\subsection{The score of English learning strategies}

The average score of English reading competencies of Matthayomsueksa 1 students under Nakhon Ratchasima Provincial Administration Organization was 10.315 from 30 items. Interpretative competencies were the top, whereas literal competencies and critical competencies were lower in descending order as shown in table 2.

Table 2

The result of analysis of English reading competencies.

\begin{tabular}{lcccc}
\hline $\begin{array}{l}\text { English reading } \\
\text { competencies }\end{array}$ & $\mathrm{N}$ & $\mathrm{K}$ & $\bar{X}$ & $\mathrm{~S} . \mathrm{D}$. \\
\hline Literal competencias & 314 & 10 & 3.636 & 1.786 \\
Interpretative competencies & 314 & 10 & 3.754 & 1.871 \\
Critical competencias & 314 & 10 & 2.923 & 1.439 \\
\hline \multicolumn{1}{c}{ Overall } & & 30 & 10.315 & 3.754 \\
\hline
\end{tabular}

When this result was interpreted, it highlighted that the test was difficult because test difficulty was .23 - .49. Critical competencies was the lowest item. They are reading competencies about integrating the reader's emotion and experience to the text, mentioning writing objectives, analyzing events between opinion and fact, and identifying valuable or useless text. It was represented that the students had got moderately thier implementing English skills and the integrated skills between background knowledge and reading context. This is the same ideas of the National Institute of Child Health and Human Development (2000), Hood and Burns (2002), and Bawornrattanaset $(2014 ; 2015)$ that the readers should relate reading text to their own experience. They had a variety of knowledge about vocabulary, grammar, accurate language patterns, language suitable to situation, thinking skills and understanding the objectives of the reading text.

\subsection{The level of behaviour on English reading competencies}

Matthayomsueksa 1 students under Nakhon Ratchasima Provincial Administration Organization somtimes apply their English learning strategies in their learning. It was shown that the level of behavior on English learning strategies was sometimes using strategies $(\bar{X}=2.982)$. They sometimes used social strategies at the top, whereas cognitive strategies, affective strategies, meta-cognitive, compensatory strategies, memory strategies were sometimes utilized in descendant order respectively as shown in table 3. 
Table 3

The analysis of level of behavior

on English learning strategies.

\begin{tabular}{lcccc}
\hline $\begin{array}{c}\text { Behavior on English } \\
\text { learning strategies }\end{array}$ & $\mathrm{N}$ & $\bar{X}$ & S.D. & Interpretation \\
\hline Cognitive strategies & 314 & 3.034 & .742 & Sometimes \\
Memory strategies & 314 & 2.909 & .746 & Sometimes \\
Compensatory strategies & 314 & 2.922 & .786 & Sometimes \\
Meta-cognitive strategies & 314 & 2.965 & .747 & Sometimes \\
Affective strategies & 314 & 3.017 & .787 & Sometimes \\
Social strategies & 314 & 3.044 & .780 & Sometimes \\
\hline
\end{tabular}

From the table 3, Social Strategies were applied in students' learning. it highlighted that nowadays teaching English has changed and is supported by the communicative approach (Wiriyachitra, et al, 2012). The students have had a lot of chances to practise English used in real situations or in simulated situations inside their classroom. They could communicate and interact with their friends, teachers and others in English. When they practised their English continually, they were confident, fluent and effective in English communication (Ellis, 2003; Willis \& Willis, 2007). In Thailand, the students lacked the opportunity to keep in touch with others in English. Their English learning automatically occurred in integrating, grouping, translating, and summarizing the main idea. These techniques helped the students to learn more efficiently, more easily and in less time. They could apply and adapt their own knowledge with new contexts. Social strategies were indirect strategies to student learning (Tunjitanont, 2016). It corresponded with English learning strategies as classified by Oxford (1990; 2003).

\subsection{Correlation analysis of English learning strategies and English reading competencies}

Each variable of English learning strategies and English reading competencies were positive interior correlation coefficients with a statistical significance at .01 level, as shown in table 4

Table 4

Correlation coefficient between English learning strategies $\left(X_{n}\right)$ and English reading competencies $\left(Y_{n}\right)$.

\begin{tabular}{|c|c|c|c|c|c|c|c|c|c|}
\hline Variable & $X_{1}$ & $x_{2}$ & $x_{3}$ & $X_{4}$ & $x_{5}$ & $X_{6}$ & $Y_{1}$ & $Y_{2}$ & $Y_{3}$ \\
\hline$X_{1}$ & 1.000 & $.847^{* *}$ & $.724^{* *}$ & $.781^{* *}$ & $.761^{* *}$ & $.693 * *$ & $.201^{* *}$ & $.135^{*}$ & .037 \\
\hline$x_{2}$ & & 1.000 & $.741^{* *}$ & $.810 * *$ & $.801^{* *}$ & $.685^{* *}$ & $.226^{* *}$ & .088 & .066 \\
\hline$x_{3}$ & & & 1.000 & $.759 * *$ & $.712^{* *}$ & $.648^{* *}$ & $.259 * *$ & .108 & .056 \\
\hline$X_{4}$ & & & & 1.000 & $.877^{* *}$ & $.764 * *$ & $.307^{* *}$ & $.118^{*}$ & .037 \\
\hline$X_{5}$ & & & & & 1.000 & $.804 * *$ & $.308 * *$ & $.116^{*}$ & .009 \\
\hline$x_{6}$ & & & & & & 1.000 & $.259 * *$ & $.132 *$ & .003 \\
\hline$Y_{1}$ & & & & & & & 1.000 & $.474^{* *}$ & $.187^{* *}$ \\
\hline$Y_{2}$ & & & & & & & & 1.000 & $.223^{* *}$ \\
\hline$Y_{3}$ & & & & & & & & & 1.000 \\
\hline
\end{tabular}

* statistically significant at .05 level

** statistically significant at .01 level

The interior correlation coefficients of English learning strategies $\left(r X_{1}-X_{6}\right)$ were between $.648-.877$, while the interior correlation coefficients of English reading competencies $\left(r Y_{1}-Y_{3}\right)$ were between $.187-.474$. Exterior correlation coefficients $\left(\mathrm{rY}_{1} *\left(\mathrm{X}_{1}-\mathrm{X}_{6}\right), \mathrm{rY} 2^{*}\left(\mathrm{X}_{1}-\mathrm{X}_{6}\right)\right)$ had positive statistical significance at .01 level and .05 level (between .116 - .308) except critical competencies which were related to every variable of English learning 
strategies $\left(r Y 3^{*}\left(X_{1}-X_{6}\right)\right)$ with no statistical significance. Furthermore, memory $\left(X_{2}\right)$ and compensatory $\left(X_{3}\right)$ strategies were relevant with interpretative competencies $\left(Y_{2}\right)$ with no statistical significance. With detailed consideration, it was found that highest exterior correlations more than .300 were 2 sets: affective strategies and literal competencies $\left(r X_{5} * Y_{1}=.308\right)$, and meta-cognitive strategies and literal competencies $\left(r X_{4} * Y_{1}=.307\right)$ as well.

It was shown that the variables of English learning strategies and English reading competencies were positive interior correlation coefficients with a statistical significance at .01 level and were appropriate to explore the canonical correlation coefficient. Because the relationships between variables in each group and between groups must be linear.

Furthermore, the canonical correlation coefficient between the set of English learning strategies and the set of English reading competencies was shown in 3 functions (table 5)

Table 5

Canonical correlation coefficient

\begin{tabular}{ccccc}
\hline $\begin{array}{c}\text { Function } \\
(\mathrm{F})\end{array}$ & $\begin{array}{c}\text { Canonical } \\
\text { correlation }\left(\mathrm{R}^{2}{ }_{\mathrm{c}}\right)\end{array}$ & Eigen value $(\lambda)$ & Wilks' lamda $(\Lambda)$ & $\begin{array}{c}\text { Chi-square } \\
\left(\chi^{2}\right)\end{array}$ \\
\hline 1 & $.349^{* *}$ & .138 & .803 & 3.874 \\
\hline 2 & $.278^{* *}$ & .084 & .914 & 2.820 \\
\hline 3 & .099 & .010 & .990 & .755 \\
\hline
\end{tabular}

** statistically significant at .01 level

The canonical correlation in function 1 was .349, the canonical correlation in function 2 was .278, and the canonical correlation in function 3 was .009. Function 1 and function 2 were correlated with positively statistical significance at .01 level. On the other hand, function 3 was correlated with no statistical significance. Function 1 correlation coefficient was the highest. The set of English learning strategies and the set of English reading competencies were related in 13.80 percent. It was hypothesized that English learning strategies were correlated to English reading competencies. It was shown that variables of English learning strategies and English reading competencies were exterior correlation coefficients, and suitable for canonical analysis. It was supported by Meejang (2001) that we consider two random variables $x$ and $y$ with zero mean. The canonical correlations between $x$ and $y$ can be found by solving the eigenvalue equations where the eigenvalues are the squared canonical correlations and the eigenvectors are the normalized canonical correlation basis vectors. The number of non-zero solutions to these equations are limited to the smallest dimensionality of $x$ and $y$. If the dimensionality of $x$ and $y$ is 8 and 5 respectively, the maximum number of canonical correlations is 5 . Only one of the eigenvalue equations needs to be solved since the solutions are relate.

It was highlighted that affective and meta-cognitive strategies were the ways of indirect learning. They were created in English learning techniques with increasing their own emotion and confidence so that they could continue their efforts and succeed their own goals, including with checking their own knowledge, opinion, and understanding in order to define learning objectives, learning plans, and English learning abilities. They were related to literal competencies which were the fundamentals of English reading. The more often students make an effort, are confident, check knowledge, and explore cognitive understanding, the higher scores of literal competencies they get. This makes the students more confident. It concurs with the research of Bowornwattanaset (2014). It was said that indirect factors affecting English reading competencies were affection and self-concept. In addition, it was connected with the research of Tunjitanont (2016). It was revealed that after studying through meta-cognitive and social activities, English reading competencies and social competencies were higher and passed the criteria. It supported their English reading competencies. 


\subsection{The canonical correlation and canonical standard weight between the set of English learning strategies and the set of English reading competencies}

From table 6 and table 7, it can be seen that the variables of canonical correlation coefficient between English learning strategies and English reading competencies were revealed in 2 functions.

Table 6

Canonical correlation and canonical standard weight between the set of English learning strategies and the set of English reading competencies with the statistic significant test of canonical correlation coefficient.

\begin{tabular}{llcc}
\hline Type of variables & \multicolumn{1}{c}{ Variables } & \multicolumn{2}{c}{ Canonical standard weight } \\
& & Function 1 & Function 2 \\
\hline English learning & Cognitive strategies & .157 & $-1.488^{*}$ \\
strategies & Memory strategies & $.602^{1}$ & $\mathbf{1 . 5 8 1}^{1}$ \\
& Compensatory strategies & $-.501^{*}$ & $-.609^{*}$ \\
& Meta-cognitive strategies & $-.343^{*}$ & $\mathbf{1 . 0 5 6}^{1}$ \\
& Affective strategies & $-.838^{*}$ & $-.459^{*}$ \\
& Social strategies & -.004 & -.850 \\
\hline English reading & Literal competencias & $-1.037^{*}$ &. $\mathbf{3 7 4}^{\mathbf{1}}$ \\
competencies & Interpret competencies & .076 & $-.599^{*}$ \\
& Critical competencias & $.338^{1}$ &. $\mathbf{9 1 1}^{1}$ \\
\hline
\end{tabular}

${ }^{*}$ Correlation in $1^{\text {st }}$ version of that function ${ }^{1}$ Correlation in $2^{\text {nd }}$ version of that function and the criteria of canonical correlation standard weight was $\geq .2$

Table 7

The canonical correlation coefficient of English learning strategies and English reading competencies.

\begin{tabular}{ccll}
\hline \multicolumn{2}{c}{ Canonical correlation coefficient } & English learning strategies & English reading competencies \\
\hline $\mathbf{1}^{\text {st }}$ & $\mathbf{1}^{\text {st }}$ version & Memory strategies & Critical competencias \\
\cline { 2 - 4 } & $2^{\text {nd }}$ version & Affective strategies & Literal competencias \\
& & Compensatory strategies & \\
\hline $\mathbf{2}^{\text {nd }}$ & & Meta-cognitive strategies & \\
function & $1^{\text {st }}$ version & Memory strategies & Critical competencies \\
& & Meta-cognitive strategies & Literal competencias \\
\cline { 2 - 4 } & $2^{\text {nd }}$ version & Cognitive strategies & Interpretative competencies \\
& & Social strategies & \\
& & Compensatory strategies & \\
& Affective strategies & \\
& &
\end{tabular}

Each function has 2 versions. The $1^{\text {st }}$ version in the $1^{\text {st }}$ function expressed that memory strategies (.602) were related to critical competencies (.388). The $2^{\text {nd }}$ version in the $1^{\text {st }}$ function exhibited that affective strategies (.838), compensatory strategies (-.501), and meta-cognitive strategies (-.343) were associated with literal competencies (-1.037). Meanwhile, the $1^{\text {st }}$ version in the $2^{\text {nd }}$ function indicated that memory strategies (1.581) and meta-cognitive strategies (1.056) were relevant to critical competencies (.911) and literal competencies (.347). The $2^{\text {nd }}$ version in the $2^{\text {nd }}$ function showed that cognitive strategies $(-1.488)$, social strategies $(-.850)$, 
compensatory strategies (-.609) and affective strategies (-.459) were correlated to interpretative competencies (-.599).

The $1^{\text {st }}$ function of the canonical correlation coefficient between English learning strategies and English reading competencies was discussed due to its high value. It was shown that critical competencies were English reading competencies about integrating reader's emotion and experience to the text, mentioning writing objectives, analyzing events between opinion and fact, identifying valuable or useless text. Additionally, reflecting the writer's emotion or feeling, specifying the meaning of the writer's idea, and connecting the text's events were considered. They were correlated to memory strategies.

This highlighted that teachers should support English reading competencies methodology and activities emphasizing the students' English learning strategies in gaining, remembering and recognizing to integrate their own knowledge with new information. They were the direct strategies that students should continually practice and do by themselves. They occurred in students' habits and characteristics. The more memory strategies students used, the more English reading competencies they got. On the contrary, the more English reading competencies students got, the more memory strategies they explored.

It was the same as Zarei's research (2002). She said that extensive reading competencies would be increased when the students created their own motivations including integrating their own knowledge, culture, inspiration, and experiences with new information. It was in accordance with the affective and memory strategies definition of Oxford (2003). Moreover, the research of Jangsangthong (2016) and Soranasataporn (2017) found that most university students used not only memory strategies to memorize the words' meaning, but also cognitive strategies to analyze the reasons and to summarize the texts.

Meanwhile, the canonical correlation coefficient between English learning strategies and English reading competencies in the $2^{\text {nd }}$ version of the $1^{\text {st }}$ function were clarified. It was found that affective, compensatory and meta-cognitive strategies were correlated to literal understanding because they were the approaches to receive the information, to continually create their own confidence and efforts in order to succeed in their goals. Furthermore, they were used to interpret the context, as well as to check their own knowledge, opinion, and understanding in order to define learning objectives, learning plans, and English learning abilities.

They were indirect strategies that teachers should support the students to continually practice. They influenced the students' literal competencies: telling the meaning of words and the main idea in the text, indicating the text details, compensating pronoun, sequencing the events, defining the character of people in the text, and following the instructions and exposition. If literal competencies got higher, students' confidence would increase. This was similar to the research of Luangwong (2014), Meandee (2014), Abdelmalek (2015), Tunjitanont (2016), Cosentino (2017). They found that meta-cognitive, social and compensatory strategies supported the students' English reading competencies to get higher scores. Thus, the more English learning strategies teachers support, the higher English reading competency scores the students get.

\section{Conclusions}

The average score of English reading competencies and sometimes behaviour level on English learning strategies were considered; moreover, they were related with positively statistical significance at .01 level. All schools under Nakhon Ratchasima Provincial Administration Organization and schools in Thailand should explore these results in order to develop their fundamental methodology in English curriculum and instruction.

Furthermore, the canonical variable analysis showed that the memory strategies were correlated with critical comprehension, and the set of affective strategies, compensatory strategies and metacognitive strategies were correlated with literal comprehension. As a result, teachers under Nakhon Ratchasima Provincial Administration 
Organization and teachers in Thailand who teach English should review their teaching and improve their methodology and teaching resources as well as their English instructional model.

From this research finding, a new research question should be considered whether and why it is the correlation between the memory strategies and critical reading competencies.

\section{Bibliographic references}

Abdelmalek, M. (2015). Research on Reading Strategies: Results from High and Low readers, Native and Nonnative English Speakers, and Male and Female Students. Los Angeles: California State University.

Arunruang, A. (2017). "English Learning Strategies for $2^{\text {nd }}$ University students in Art Faculty, Rajamangala University of Technology Phra Nakhon" in $9^{\text {th }}$ Rajamangala University of Technology Academic Conference. Nakhon Pathom: Rajamangala University of Technology Rattanakosin.

Bowornwattanaset, C. (2014). "The Causal Factors Influencing English Reading Comprehension Ability of Lower Secondary School Students" in RMUTSB Academic Journal. Vol. 2 No. 2 pp. 183-19

Bowornwattanaset, C. (2015). "The Development of an English Reading Comprehension Instructional Model for Lower Secondary School Students" in National and International Conference Interdisplinary Research for Local Development Sustainability. The $15^{\text {th }}$ proceeding report of Nothern Ratjabhat University. Nakhon Sawan: Nakhon Sawan Ratjabhat University. pp. 327-340.

Cosentino, C. (2017). "The Effect of Self-Regulation Strategies on Reading Comprehension, Motivation for Learning, and self-efficacy with Struggling Readers" in Education Dissertations. 68. Retrieved from https://repository.wcsu.edu/educationdis/68

Ellis, R. (2003). Task-based Language Learning and Teaching. Oxford: Oxford University Press.

Hanh Thi Bich Nguyen. (2014). Second Language Reading Strategies: Evidence from Vietnamese learners of English. Illinois: Southern Illinois University Carbondale.

Hood, S., Solomon, N., Burns, A. (2002). Focus on Reading. Sydney: NCELTR.

Jangsangthong, W. (2016). "English Reading Strategies among Thai students studying English as a foreign language" in $6^{\text {th }}$ Journal of Graduate Studies in Northern Rajabhat University. No. 11. July - December 2016.

Lee, K. and Yoo, J. (2014)._Canonical Correlation Analysis Through Linear Modeling in Volume 56, Issue 1. Pp 199. retrieved from Onlinelibrary.wiley.com/doi/epdf/10.1111/anzs. 12057. In March 13, 2020.

Luangwong, N. (2014). The Awareness Integration of Meta-cognitive Strategies in Reading Teaching to Promote English Reading Comprehension of Mathayomsuksa 3 students. Nakhon Ratchasima: Nakhon Ratchasima Rajabhat University.

Meandee, R. (2014), "Using Metacognitive Strategies to Improve Business Reading Comprehension of Buriram Rajabhat University Students" in Research and Development Journal Buriram Rajabhat University. Vol. 9 No. 1 (January - June). pp. $11-122$.

Meejang, S. (2001). Advance Statistics for research. Bangkok: Naresuan University.

Mayberry, K. (2017). "The Effects of Small Group Strategy Instruction on the Reading Comprehension of First Grade ELL Students" in ProQuest LLC. Ed.D. Dissertation. Tennessee: Trevecca Nazarene University. 
Mermelstein, A. (2015). "Reading Level Placement and Assessment for ESL/EFL Learners: The Reading Level Measurement Method" in ORTESOL Journal. Vol. 32.

Nitiwatthana, K. (2016), The study of English Language Learning Strategies Used by Second-year Students of the Faculty of Education, Chaiyaphum Rajabhat University. Bangkok: Ramkhamhaeng University.

ONESQA. (2017). The Guidelines Framework for $4^{\text {th }}$ External Quality Assessment (2016-2020). The Board of ONESQA committees approved the meeting No.10 / 2017 on September $12^{\text {th }}, 2017$.

Oxford, R. (1990). Language learning strategies: what every teacher should know. New York: Newbury House Publishers.

Oxford, R. (2003). Language Learning Styles and Strategies: An Overview. GALA, pp. 1-25.

Oxford, R., et al. (2014). "The learning strategy prism: Perspectives of learning strategy experts". System, No. 43, 30-49. Retrieved from http://dx.doi.org/10.1016/j.system.2014.02. 004.

Schumaker, J., \& Deshler, D. (2006). "Teaching adolescents to be strategic learners" in D. D. Deshler and J. B. Schumaker (Eds.), Teaching adolescents with disabilities: Accessing the general education curriculum (pp. 121-156). Thousand Oaks, CA: Corwin Press.

Soranastaporn, S. (2017). "Direct Language Learning Strategies of That learners in Thailand 4.0" in Journal of Humanities and Social Sciences, Thonburi University. Vol. 11 No. 26 September - December, 2017. pp. 923.

Stoffelsma, L. (2019). “The Relationship Between English Reading Proficiency and Academic Achievement of First-Year Science and Mathematics Students in a Multilingual Context" in International Journal of Science and Mathematics Education Vol. 17, No. 5 (June), pp. 905-922.

Tunjitanont, P. (2016). “English Reading Ability and Social Skills of the Undergraduates' Learning through Integrated-Learning Activities of Metacognitive and Social Strategies." In Ratchaphruek Journal. Vol.14 No.2 (May - August) pp. 1-9.

Willis, D. \& Willis, J. (2007). Doing Task-Based Teaching: A practical guide to task-based teaching for ELT training courses and practising teachers. Oxford: Oxford University Press.

Wiriyachitra, A. et al. (2012). Looking Back and Moving Forword of English Teaching. Bangkok: Window on Education Company.

Zarei, G. (2002). A developmental study of EFL reading comprehension and metacognition processes: $A$ constructivist vs. transmissional approach. Unpublished Ph.D. Dissertation. Iran: University of Isfahan.

Esta obra está bajo una Licencia Creative Commons Attribución-NoCommercial 4.0 International

(c) EY-NG 